\title{
FT-IR spectromicroscopy of mammalian cell cultures during necrosis and apoptosis induced by drugs
}

\author{
Annalisa Lamberti ${ }^{\text {a }}$, Carmen Sanges ${ }^{\text {a }}$ and Paolo Arcari ${ }^{\mathrm{a}, \mathrm{b}, *}$ \\ ${ }^{a}$ Dipartimento di Biochimica e Biotecnologie Mediche, Università di Napoli Federico II, Napoli, Italy \\ ${ }^{\mathrm{b}}$ CEINGE Biotecnologie Avanzate Scarl, Napoli, Italy
}

\begin{abstract}
FT-IR is used in the field of biology and medicine to detect bimolecular changes in disordered cells and tissues. In this report, using FT-IR microscopy, we characterize changes in apoptotic and necrotic Jurkat cells with respect to normal cells. The analysis of deconvoluted regions of the FT-IR spectra showed significant differences compared to the controls in three spectral regions. In particular, the apoptotic cells were characterized by an increase in the absorption at $2925 \mathrm{~cm}^{-1}$, due to the asymmetric $\mathrm{CH}_{2}$-stretching $\left(\nu_{\mathrm{as}} \mathrm{CH}_{2}\right)$ of membrane lipids whereas the spectral areas ratio $\left(\mathrm{A}_{1654} / \mathrm{A}_{1629}\right)$ of the amide I region indicated an increase in apoptotic cells of more $\alpha$-helical structures with respect to of $\beta$-sheet content. Interestingly, apoptotic cells showed the appearance of a peak around $1743 \mathrm{~cm}^{-1}, \nu(\mathrm{C}=\mathrm{O})$ assigned to acid ester. Because no other similar increase for lipid bands was observed, the increase of $\mathrm{A}_{1745}$ is not simply due to an increase in the number of lipid molecules or their density but could also be indicative as marker of apoptosis. These spectral changes were not observed in necrotic Jurkat cells.
\end{abstract}

Keywords: FT-IR micro-spectrometry, apoptosis, necrosis

\section{Introduction}

Techniques providing chemical information within living cells and tissues represent a very powerful tool for biomedical research directed toward the understanding of the causes of disease onset and on the properties and functions of diseased cells. Fourier Transformed Infrared spectromicroscopy (FT-IR-MC) has the potential to provide biochemical information without disturbing the biological sample. Moreover, it combines infrared spectroscopy, a sensitive analytical chemistry technique, with microscopy to enable detailed chemical analysis on a microscopic scale. Therefore, the FT-IR analysis of biological cells and tissue can determine whether cells or tissue are cancerous. Many important biological macromolecules, like nucleic acids [35], proteins [34] and lipids [19] have characteristic and well-defined IR-active vibrational modes thus, the analysis of IR spectra can detect, identify and quantify several molecular species within a biological sample. Under this aspects, FT-IR spectroscopy has been use to study variation in the conformation of biological macromolecules occurring between normal cells and cancer cells $[1,2,4$, $11,23,28,31]$. In addition, FT-IR spectroscopy represents also an important tool for the comprehension

\footnotetext{
${ }^{*}$ Corresponding author: Dr. Paolo Arcari, Dipartimento di Biochimica e Biotecnologie Mediche, Università di Napoli Federico II, Via S. Pansini 5, I-80131, Napoli, Italy. Tel.: +39 081 7463120; Fax: +39 081 7463653; E-mail: paolo.arcari@ unina.it.
} 
of the interactions between living cells and their surrounding environments [37]. (The main advantages of this technique are simple, quick and economically viable).

In this study, changes in Jurkat cells during apoptosis or necrosis were studied using FT-IR microspectroscopy. With respect to necrosis, Jurkat cells showed significant conformational changes during apoptosis.

\section{Materials and methods}

\subsection{Materials}

RPMI 1640 medium and bovine fetal serum (FBS) were purchased from Lonza (Basel, Switzerland). Tissue culture plastic-ware was from Becton-Dickinson Labware (Franklin Lakes, NJ, USA). Propidium iodide was purchased from Sigma (Milan, Italy).

\subsection{Cell growth and apoptosis}

Human leukemic T cell line (Jurkat) obtained from American Type Tissue Collection (Rockville, MD, USA), was grown in RPMI 1640 medium supplemented with $10 \%$ heat inactivated fetal bovine serum, $100 \mathrm{U} / \mathrm{ml}$ penicillin, $100 \mu \mathrm{g} / \mathrm{ml}$ streptomycin, $1 \% \mathrm{~L}$-glutamine at $37^{\circ} \mathrm{C}$ in a $5 \% \mathrm{CO}_{2}$ atmosphere up to a concentration of $5 \times 10^{5}$ cells/ml [15]. Apoptosis was induced treating cells with Etoposide phosphate (VP-16) $(50 \mu \mathrm{M})$ or Cis-Platinum (Cis-P) $(25 \mu \mathrm{M})$ [7,17]. After drug treatment, either at 8 , 16,24 and $32 \mathrm{~h}$ or at different drug concentration $(1,5,10,20,30 \mu \mathrm{M}$ for $48 \mathrm{~h})$, cells were collected by centrifugation at $1500 \mathrm{rpm}$ for $5 \mathrm{~min}$, washed twice with $100 \mu \mathrm{l}$ of PBS and resuspended in $10 \mu \mathrm{l}$ PBS for FT-IR analysis. Necrosis of Jurkat cells [30] was induced at a concentration of $5 \times 10^{5}$ cells $/ \mathrm{ml}$ by depriving the cell suspension of oxygen for 24,48 and $96 \mathrm{~h}$. Apoptosis or necrosis was evaluated by Propidium iodide and FACScan flow cytometer (Becton-Dickinson).

\subsection{FT-IR analysis}

In all experiments, $10 \mu \mathrm{l}$ of cells suspension were layered on $3 \mathrm{~mm} \mathrm{ZnS} \mathrm{window,} \mathrm{dried} \mathrm{for} 2 \mathrm{~min}$ under a 60 watt white light $(10 \mathrm{~cm}$ distant $)$ and analyzed with a Nicolet 5700 equipped with a microscope Continumm (Thermo). For each sample, spectra (200 acquisitions) were collected always in transmission by using the microscope focusing windows set at $50 \times 50 \mu \mathrm{m}$. Spectra were analyzed by using the Omnic software. Curve fit analysis of deconvoluted spectra was performed by using the OriginPro 7.5 software.

\section{Results and discussion}

\subsection{Cellular changes in Jurkat cells}

As reported in Table 1, the best condition for apoptosis was obtained by treating Jurkat cells with VP-16 for $32 \mathrm{~h}$. Jurkat cells collected at different apoptotic stage or different necrotic stage were then analyzed by FT-IR microscopy. Representative FT-IR spectra of normal, apoptotic or necrotic cells are shown in Fig. 1. Spectra, normalized for the amide I peak, showed several absorbance changes. To evaluate these difference, the FT-IR spectra were analyzed in the regions corresponding to $\mathrm{N}-\mathrm{H}$ stretching 
Table 1

Apoptosis of Jurkat cells induced by Cis-platinum and VP-16

\begin{tabular}{lcc}
\hline & Time $(\mathrm{h})$ & Apoptosis $(\%)$ \\
\hline No-treatment & 0 & 3.08 \\
Cis-P $(25 \mu \mathrm{M})$ & 8 & 3.36 \\
& 16 & 11.64 \\
& 32 & 34.24 \\
VP-16 $(50 \mu \mathrm{M})$ & 8 & 6.40 \\
& 16 & 37.28 \\
& 32 & 66.66 \\
\hline
\end{tabular}

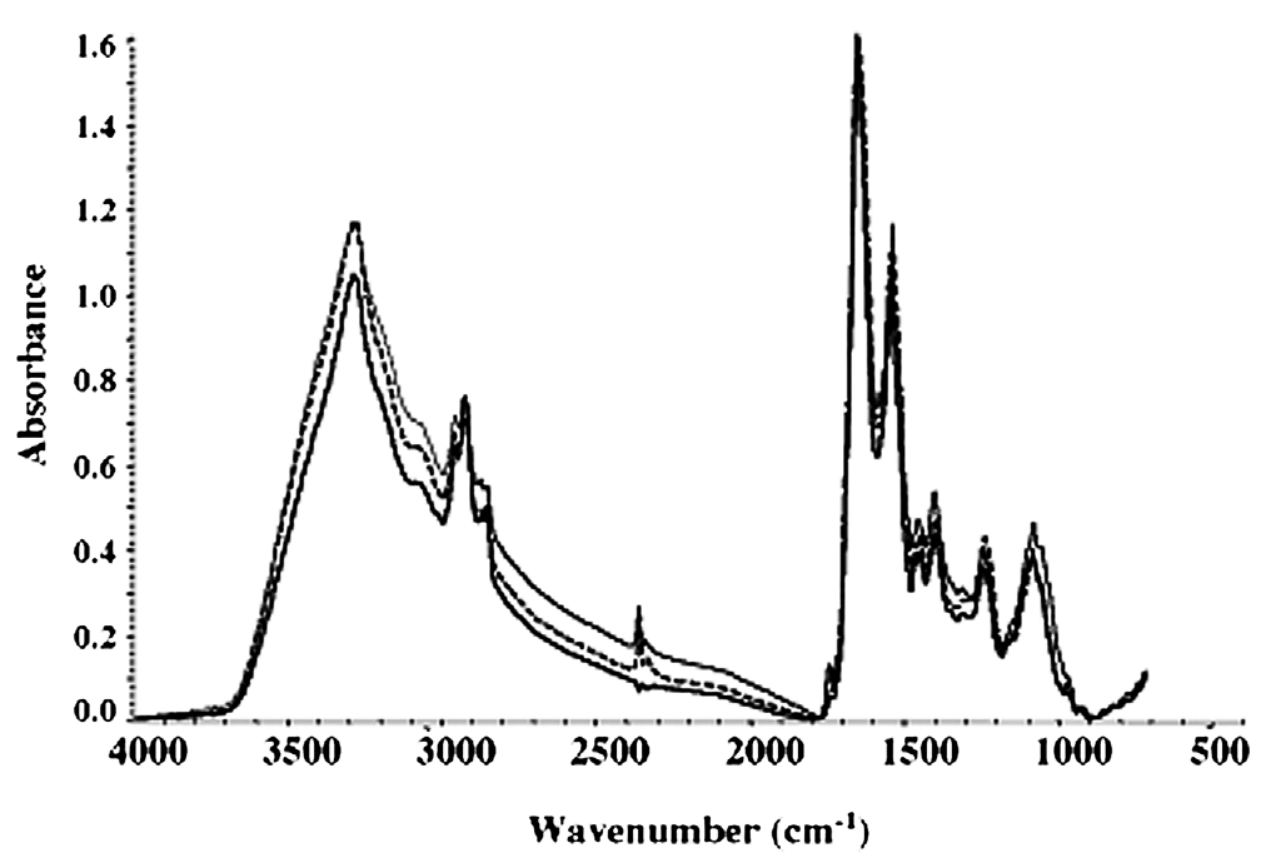

Fig. 1. FT-IR spectra of Jurkat cells expressed as arbitrary units (a.u.). Approximately equal number of normal (continuous line), apoptotic (bold continuous line) or necrotic cells (dashed line) were spotted onto a ZnSe window, dried and analyzed under the IR microscope using $50 \times 50 \mu \mathrm{m}$ window.

(3600-3000 $\left.\mathrm{cm}^{-1}\right)$, C-H stretching $\left(2800-3100 \mathrm{~cm}^{-1}\right)$, amide I $\left(1750-1600 \mathrm{~cm}^{-1}\right)$, amide II (1600$\left.1480 \mathrm{~cm}^{-1}\right)$, amide III $\left(1300-1180 \mathrm{~cm}^{-1}\right)$ and DNA region $\left(1300-800 \mathrm{~cm}^{-1}\right)$. The use of spectral areas derived from IR deconvolution rather than absolute optical density on selected absorbance was considered more informative [26].

\subsection{The $N-H$ stretching region}

The deconvolution of the IR spectra in this region (Fig. 2) showed the presence of five peaks around the frequencies $3060,3174,3293,3417$ and $3534 \mathrm{~cm}^{-1}$. The frequencies at 3293 and $3060 \mathrm{~cm}^{-1}$ can be generally assigned to the $\mathrm{N}-\mathrm{H}$ stretching of proteins and nucleic acids (amide band $\mathrm{A}$ and $\mathrm{B}$ ) whereas the band at $3417 \mathrm{~cm}^{-1}$ and $3174 \mathrm{~cm}^{-1}$ represent the $\mathrm{N}-\mathrm{H}$ stretching bands of trans- and cis-ordered structures [5]. Evaluation of the absorbance peak area ratio $\mathrm{A}_{3293} / \mathrm{A}_{3060}$ of the $\mathrm{N}-\mathrm{H}$ stretching bands 


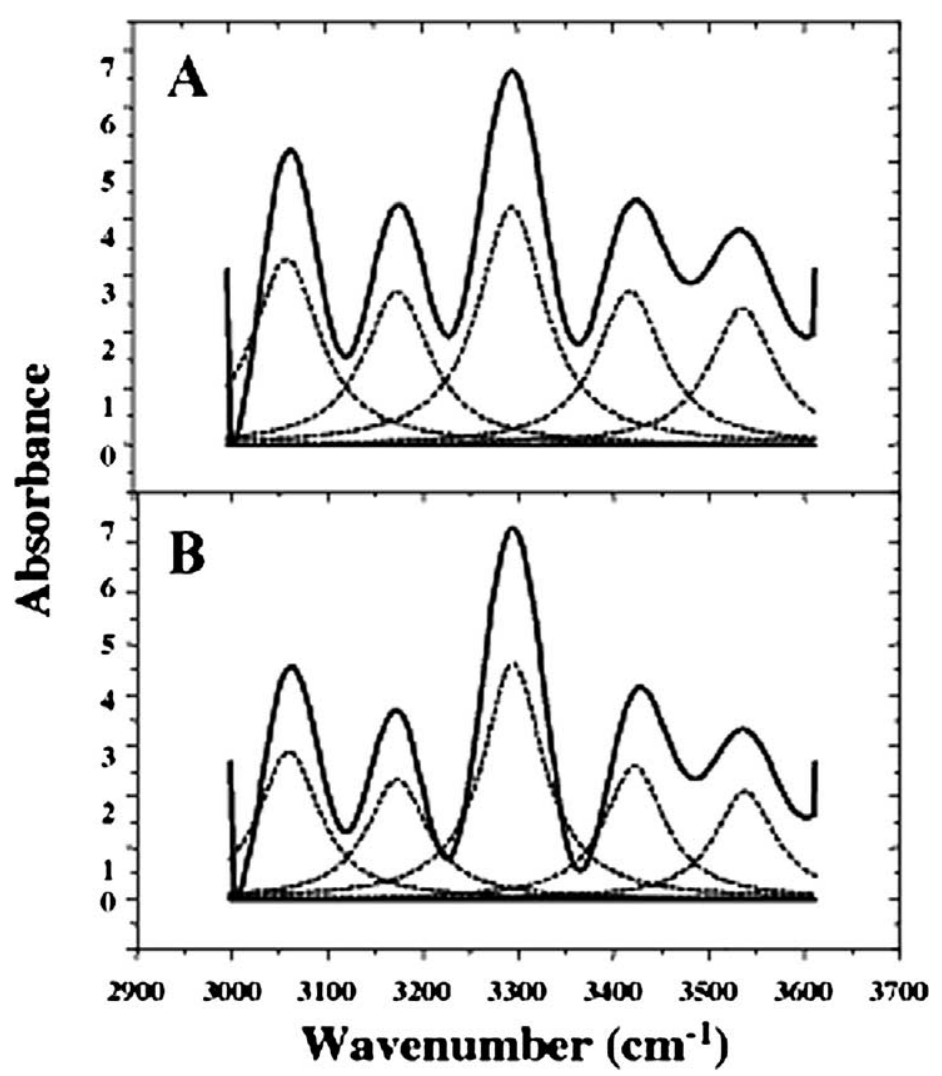

Fig. 2. Deconvoluted IR spectra in the frequency region $3600-3000 \mathrm{~cm}^{-1}$ of Jurkat cells with enhancement factor 3.0 and bandwidth $250 \mathrm{~cm}^{-1}$. (A) Normal cells; (B) cells after $32 \mathrm{~h}$.

showed a progressive increase from control cells to cells treated with drugs at different times (Table 2a) and concentrations (Table 2b). The increase in the ratio was mainly due to the increase of the $3293 \mathrm{~cm}^{-1}$ peak area whereas the peak at $3060 \mathrm{~cm}^{-1}$ remained almost constant. This behaviour was also observed in Jurkat cells treated with rapamicin (control, $1.17 \pm 0.06$; rapamicin $32 \mathrm{~h}, 1.87 \pm 0.04$ ) and in $\mathrm{KB}$ cells treated with VP-16 (control, $1.35 \pm 0.05$; VP-16 $32 \mathrm{~h}, 2.36 \pm 0.04$ ). We also analyzed the behaviour of Jurkat cells during necrosis. As reported in Table 2c, with respect to apoptotic cells, the $\mathrm{A}_{3293} / \mathrm{A}_{3060}$ of the $\mathrm{N}-\mathrm{H}$ stretching bands at 24,48 and $96 \mathrm{~h}$ of necrosis remained almost unchanged. Because the intensity of the band at $3060 \mathrm{~cm}^{-1}$ is supposed to decrease with increasing dilution [18], this result might suggest that the apoptotic cell showed a more dense and close-packed structure with respect necrotic cells [5].

\subsection{The $C-H$ stretching region}

FT-IR spectra in this region could furnish information regarding the oxidative damage of phospholipids. The deconvoluted spectra showed the presence of six peaks (Fig. 3). The band around 2850 and $2870 \mathrm{~cm}^{-1}$ is mainly due to the symmetric stretching of $\mathrm{CH}_{2}\left(\nu_{\mathrm{s}} \mathrm{CH}_{2}\right)$ and $\mathrm{CH}_{3}\left(\nu_{\mathrm{s}} \mathrm{CH}_{3}\right)$ groups of membrane lipids, respectively $[9,25]$. The band around 2925 and $2960 \mathrm{~cm}^{-1}$ is due to the asymmetric $\mathrm{CH}_{2}-$ $\left(\nu_{\mathrm{as}} \mathrm{CH}_{2}\right)$ and $\mathrm{CH}_{3}$-stretching $\left(\nu_{\mathrm{as}} \mathrm{CH}_{3}\right)$ of methyl end-groups of membrane lipids, respectively, and also of the methyl amino acid side group of cellular proteins $[9,25,29,38]$. These marker bands are used to 
Table 2a

$\left(\mathrm{A}_{3300} / \mathrm{A}_{3075}\right)$ after treatment with different drugs

\begin{tabular}{lccccccc}
\hline Control & \multicolumn{3}{c}{ VP-16 $(50 \mu \mathrm{M})$} & & 3 & Cis-P $(25 \mu \mathrm{M})$ \\
\cline { 2 - 4 } \cline { 6 - 8 } & $8 \mathrm{~h}$ & $16 \mathrm{~h}$ & $32 \mathrm{~h}$ & & $8 \mathrm{~h}$ & $16 \mathrm{~h}$ & $32 \mathrm{~h}$ \\
\hline $1.48 \pm 0.05$ & $1.52 \pm 0.06$ & $1.70 \pm 0.10$ & $1.73 \pm 0.10$ & & $1.36 \pm 0.04$ & $1.44 \pm 0.06$ & $1.52 \pm 0.10$ \\
\hline
\end{tabular}

Table $2 b$

$\left(\mathrm{A}_{3300} / \mathrm{A}_{3075}\right)$ after treatment at increasing concentration of VP-16

\begin{tabular}{lccccc}
\hline Control & \multicolumn{5}{c}{ VP-16 concentration } \\
\cline { 2 - 6 } & $1 \mu \mathrm{M}$ & $5 \mu \mathrm{M}$ & $10 \mu \mathrm{M}$ & $20 \mu \mathrm{M}$ & $30 \mu \mathrm{M}$ \\
\hline $1.68 \pm 0.06$ & $1.69 \pm 0.10$ & $1.76 \pm 0.10$ & $1.82 \pm 0.04$ & $1.83 \pm 0.06$ & $1.87 \pm 0.10$ \\
\hline
\end{tabular}

Table 2c

$\left(\mathrm{A}_{3300} / \mathrm{A}_{3075}\right)$ at increasing time of oxygen deprivation

\begin{tabular}{lccc}
\hline Control & $24 \mathrm{~h}$ & $48 \mathrm{~h}$ & $96 \mathrm{~h}$ \\
\hline $2.0 \pm 0.1$ & $1.88 \pm 0.10$ & $2.12 \pm 0.10$ & $1.98 \pm 0.10$ \\
\hline
\end{tabular}

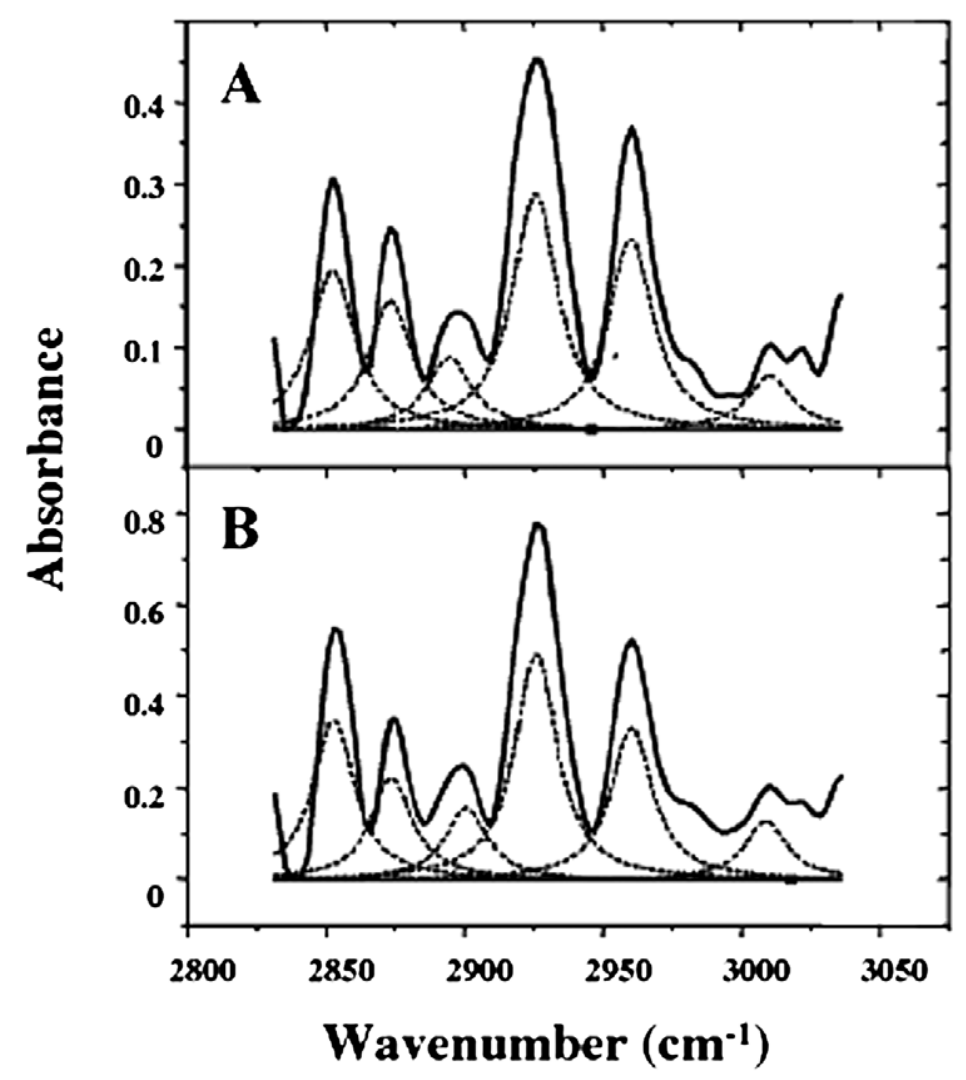

Fig. 3. Deconvoluted IR spectra in the frequency region $3000-2800 \mathrm{~cm}^{-1}$ of Jurkat cells with enhancement factor 3.0 and bandwidth $30 \mathrm{~cm}^{-1}$. (A) Normal cells; (B) cells after $32 \mathrm{~h}$ treatment with $50 \mu \mathrm{M}$ VP-16. Deconvoluted spectra (continuous line), spectral curve-fitting (dashed line). 
determine the membrane lipid content [31]. Curve fitting analysis of the absorption areas showed during apoptosis an increase with respect to untreated cells of $\nu=\mathrm{CH}\left(3010 \mathrm{~cm}^{-1}\right)$ (from 6.1 to $7.3 \%$ ) and $\nu_{\text {as }} \mathrm{CH}_{2}$ (from 28.8 to 30.2\%) and a slight decrease of the $\nu_{\text {as }} \mathrm{CH}_{3}$ peak area (from 23.3 to 21.9\%). This behaviour was also concomitant to the increase of the $\nu_{\mathrm{s}} \mathrm{CH}_{2}$ (from 17.5 to $19.2 \%$ ) and the decrease of $\nu_{\mathrm{s}} \mathrm{CH}_{3}$ (from 15.2 to $13.2 \%$ ) peak areas. The increase in the $\mathrm{A}_{2852}$ indicated a higher membrane lipid content in Jurkat cells during apoptosis compared to that of untreated cells [41]. We also observed a progressive increase of the $\nu=(\mathrm{CH}) / \nu_{\text {as }}\left(\mathrm{CH}_{3}\right)\left(\mathrm{A}_{3010} / \mathrm{A}_{2960}\right)$ and $\nu_{\text {as }}\left(\mathrm{CH}_{2}\right) / \nu_{\text {as }}\left(\mathrm{CH}_{3}\right)\left(\mathrm{A}_{2925} / \mathrm{A}_{2960}\right)$ peak ratio from untreated cells $(0.26 \pm 0.03$ and $1.23 \pm 0.10$, respectively) to cells treated for $32 \mathrm{~h}$ with VP-16 $(0.35 \pm 0.04$ and $1.31 \pm 0.08$, respectively). Comparable result was also observed in the case of Jurkat cells treated with Cis-P. In the case of necrotic Jurkat cells, the analysis of deconvoluted spectra at 0 (control), 24, 48 and $96 \mathrm{~h}$ did not show substantial differences in both peak area and ratio. In fact, the $\nu=(\mathrm{CH}) / \nu_{\text {as }}\left(\mathrm{CH}_{3}\right)$ and $\nu_{\text {as }}\left(\mathrm{CH}_{2}\right) / \nu_{\text {as }}\left(\mathrm{CH}_{3}\right)$ values were $0.50,0.48,0.58,0.48$ and 1.27, 1.17, 1.19, 1.17, respectively. The increase of $\mathrm{CH}_{2} / \mathrm{CH}_{3}$ ratio in Jurkat apoptotic cells was due to a slightly decrease of the $\nu_{\text {as }}\left(\mathrm{CH}_{3}\right)$ with respect to the $\nu_{\mathrm{as}}\left(\mathrm{CH}_{2}\right)$. From this data, it appeared that there was not a direct correlation between unsaturation and saturation level of membrane phospholipids as observed instead in the case of erythrocytes oxidative stress [26]. Also in the case of apoptotic HL60 cells, no significant changes in the $\mathrm{CH}_{2} / \mathrm{CH}_{3}$ ratio was observed [10]. These findings probably indicated that with respect to oxidative stress [26], fatty acid metabolism, evaluated by change in the $\nu_{\mathrm{as}}\left(\mathrm{CH}_{3}\right)$ absorbance [26], was changing in apoptotic Jurkat cells. It was reported that the tendency in the increase in the $\mathrm{CH}_{2} / \mathrm{CH}_{3}$ absorbance ratio might depends by cell growth conditions [3,14,20,21,33]. Because apoptosis lead to cell shrinkage [16], a decrease in the cellular volume should correspond to a relative increase in the surface area. This may cause an increase of the phospholipids fraction in the biomass, corresponding to a major enrichment in $\mathrm{CH}_{2}$ relative to $\mathrm{CH}_{3}$ groups [10].

\subsection{The amide I region}

The amide I region is often used in the study of membrane-protein structures since this region represents the most suitable probe to evaluate differences among the secondary structures of proteins and peptides [12]. The deconvolution spectra (Fig. 4) showed the presence of seven major $\nu(\mathbf{C}=\mathrm{O})$ bands around 1594, 1629, 1654, 1675, 1691, 1714 and $1745 \mathrm{~cm}^{-1}$ corresponding to amine, parallel $\beta$-strand, $\alpha$-helix, parallel $\beta$-strand, anti-parallel $\beta$-strand, lipid ester and acid ester, respectively [27]. Curve fit Analysis of the deconvoluted curves showed that the $\alpha$-helix content increased from control cell (28\%) to cell treated with VP-16 for $32 \mathrm{~h}(33.5 \%)$ whereas the peaks of $\beta$-strand at $1675 \mathrm{~cm}^{-1}$ showed a reduction (from 15.5 to $14.0 \%$ ) [13]. The $\mathrm{A}_{1654} / \mathrm{A}_{1629}$ furnishes a measure of the $\alpha$-helix and $\beta$-strand domain of proteins [5]. Here, we observed an increase of the ratio (control cell, $0.43 \pm 0.03$; Cis-P $8 \mathrm{~h}, 1.74 \pm 0.06$; Cis-P 16 h, $1.67 \pm 0.06$; Cis-P $32 \mathrm{~h}, 1.22 \pm 0.05$ ). The same evaluation made for necrotic Jurkat cells showed a tendency to remain constant or to a reduction (control, $1.10 \pm 0.04 ; 24 \mathrm{~h}, 1.15 \pm 0.04 ; 48 \mathrm{~h}$, $0.95 \pm 0.03 ; 96 \mathrm{~h}, 1.09 \pm 0.04$ ) [32]. It could be possible that the conversion from $\alpha$-helix to $\beta$-sheet structure could be due to lipid-auto-oxidation products that probably deformed the protein's secondary structure from $\alpha$-helix to $\beta$-sheet [39].

In addition, we also observed a strong increase of the peak at $1745 \mathrm{~cm}^{-1}$ (from about 6.5 to $10.5 \%$ ), usually associated with the non-hydrogen bonded ester carbonyl $\mathrm{C}=\mathrm{O}$ stretching mode within phospholipids [24], that was even more evident during treatment of Jurkat cell with increasing concentration of VP-16 (from 5.0\% control up to $12.8 \%$ at $30 \mu \mathrm{M} \mathrm{VP-16)} \mathrm{and} \mathrm{a} \mathrm{peak} \mathrm{at} 1716 \mathrm{~cm}^{-1}$, associated with hydrogen bonded $\mathrm{C}=\mathrm{O}$ groups [6], that instead showed a decrease (from 9.8 control to $6.4 \%$ ). These 


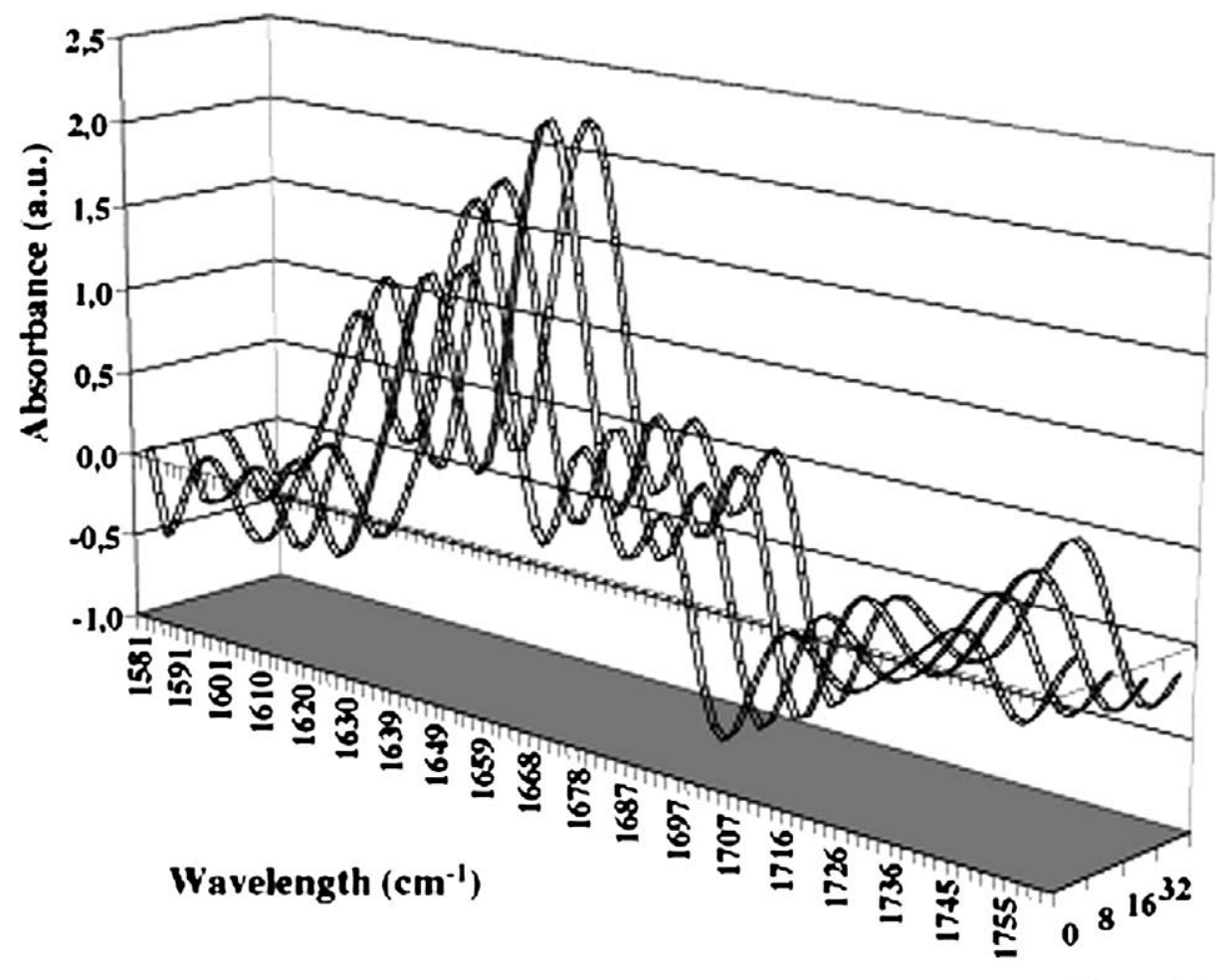

Time (h)

Fig. 4. Deconvoluted IR spectra in the frequency region $1600-1760 \mathrm{~cm}^{-1}$ of Jurkat cells with enhancement factor 3.0 and bandwidth $40 \mathrm{~cm}^{-1}$. Spectra were taken at different times of treatment of Jurkat cells with $50 \mu \mathrm{M}$ VP-16.

variations were not observed in necrotic cell. In fact, the absorbance peak area at $1745 \mathrm{~cm}^{-1}(\sim 9.1 \%$ control; $9.5 \%$ at $24 \mathrm{~h} ; 9.8 \%$ at $48 \mathrm{~h} ; 9.7 \%$ at $96 \mathrm{~h})$ and $1716 \mathrm{~cm}^{-1}(\sim 8.9 \%$ control; $8.7 \%$ at $24 \mathrm{~h} ; 8.5 \%$ at $48 \mathrm{~h} ; 8.9 \%$ at $96 \mathrm{~h}$ ) remained almost unchanged. In the latter case, an increase in the peak intensity $\left(1725 \mathrm{~cm}^{-1}\right)$ [6] was instead observed in necrotic cells. Holman et al., 2003 [13] and Jamin et al., 1998 [14] reported a similar increase in the case of IMR-90 cells that had lost membrane integrity [40]. This finding indicated that the $\mathrm{C}=\mathrm{O}$ ester carbonyl groups of lipids in apoptotic cells are becoming predominantly non-hydrogen bonded [13] which would be indicative of oxidative damage. In fact, among other factors, apoptosis is associated with increased oxidative damage [22].

\subsection{The amide II region}

The amide II region $\delta(\mathrm{N}-\mathrm{H})$, after deconvolution, showed the presence of absorption bands at 1506 , 1521,1540 (predominantly $\beta$-sheet), 1558 (predominantly $\alpha$-helix), and $1575 \mathrm{~cm}^{-1}$ (Fig. 5). This region however, is not as sensible to conformational changes as instead for the amide I bands [24]. We found that the peak area ratio $\mathrm{A}_{1558} / \mathrm{A}_{1540}$ slightly increased after treatment of the cells with drugs $(0.58 \pm 0.03$ for normal cell and $0.58 \pm 0.03,0.68 \pm 0.03$ and $0.69 \pm 0.03$ for cell treated with VP-16 at 8,16 and $32 \mathrm{~h}$, or $0.62 \pm 0.03$ for cell treated with Cis-P at 8 and $16 \mathrm{~h}$, respectively), thus suggesting an increase in the absorption of $\alpha$-helix. On the contrary, in the case of necrotic cell, the value of the $\mathrm{A}_{1558} / \mathrm{A}_{1540}$ ratio was $1.05 \pm 0.05,1.03 \pm 0.05$ and $0.98 \pm 0.03$ at 24,48 and $96 \mathrm{~h}$, respectively. Evaluation 


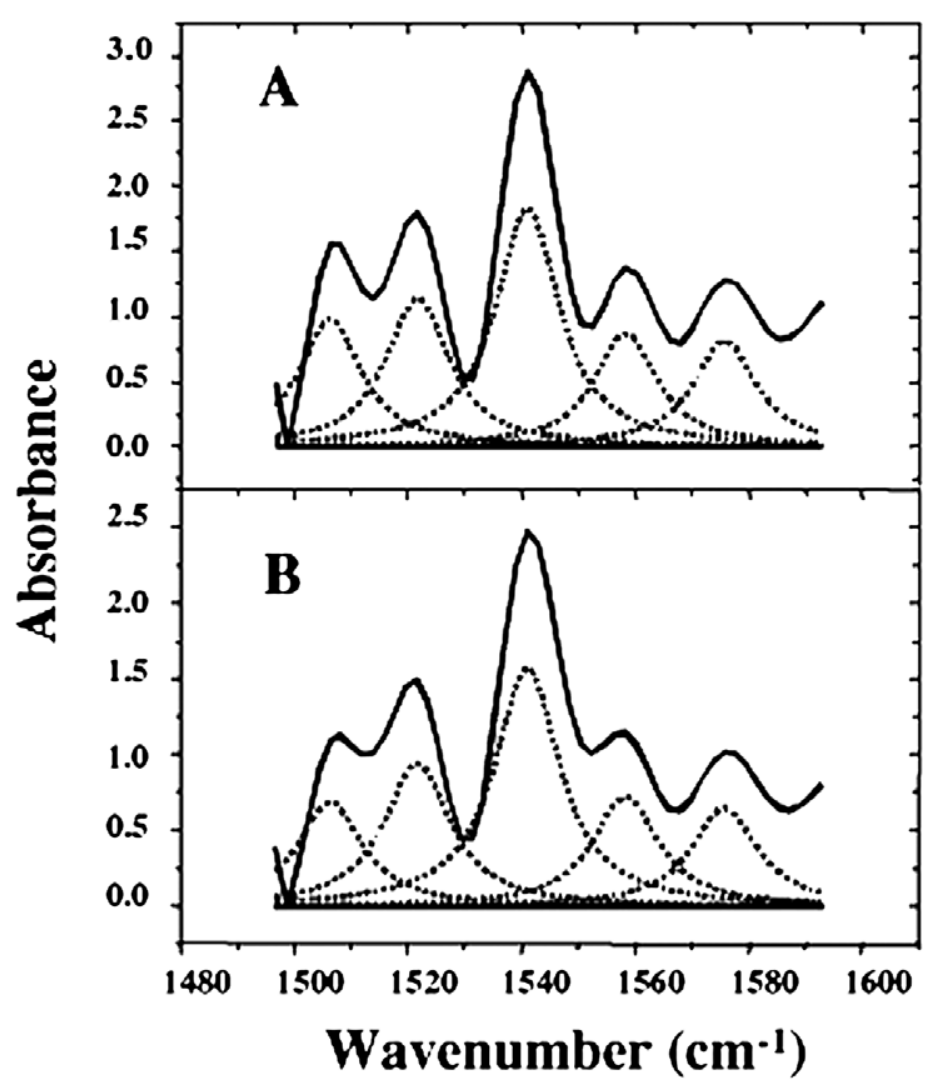

Fig. 5. Deconvoluted IR spectra in the frequency region $1600-1480 \mathrm{~cm}^{-1}$ of Jurkat cells with enhancement factor 3.0 and bandwidth $30 \mathrm{~cm}^{-1}$. (A) Normal cells; (B) cells after $32 \mathrm{~h}$ treatment with $50 \mu \mathrm{M}$ VP-16. Deconvoluted spectra (continuous line), spectral curve-fitting (dashed line).

of amide I-amide II peak area ratio $\left(\mathrm{A}_{1654} / \mathrm{A}_{1540}\right)(\alpha$-helix/ $\beta$-sheet $)$, which is often used to identify conformational changes of membrane proteins [36], showed a slight increase $(0.98 \pm 0.04$ in control cell and $0.98 \pm 0.04,1.04 \pm 0.05$ and $1.14 \pm 0.06$ for cell treated with VP- 16 at 8,16 and $32 \mathrm{~h}$, or $1.14 \pm 0.06$ for cell treated with Cis-P at 8 and $16 \mathrm{~h}$, respectively). The same evaluation made for necrotic cells showed an almost constant ratio $(0.95 \pm 0.03,0.98 \pm 0.04$ and $1.00 \pm 0.04$ at 24,48 and $96 \mathrm{~h}$, respectively).

\subsection{The amide III region}

Spectra deconvolution of the amide III region shows the presence of three peaks at 1212, 1237 and $1284 \mathrm{~cm}^{-1}$ (Fig. 6). The major band at $1237 \mathrm{~cm}^{-1}$ represents also the asymmetric stretching of phosphodiester bond $\left(\nu_{\mathrm{as}} \mathrm{PO}_{2}{ }^{-}\right)$of nucleic acid. The bands at 1212 and $1284 \mathrm{~cm}^{-1}$ of low intensity have been assigned to vibration modes of collagen proteins. Evaluation of peak area showed a slight increase of the peaks at 1212 and $1284 \mathrm{~cm}^{-1}$ with respect to control cells that was associated to a decrease of the peak area at $1237 \mathrm{~cm}^{-1}$. The $\mathrm{A}_{1657} / \mathrm{A}_{1212}$ and $\mathrm{A}_{1657} / \mathrm{A}_{1284}$ indicate the collagen content relative to total content of protein [5]. In the case of Jurkat cells, no strong differences in apoptotic or necrotic cells were found as instead observed in tumoral tissues [5]. In particular, in Jurkat cells treated with VP-16, both ratios showed a very small increase (control, $0.97 \pm 0.04$; VP-16 $8 \mathrm{~h}, 1.06 \pm 0.04$; VP-16 $32 \mathrm{~h}$, $1.07 \pm 0.04$; VP-16 $32 \mathrm{~h}, 1.11 \pm 0.05$ and control, $1.11 \pm 0.05$; VP-16 8 h, $1.15 \pm 0.06$; VP-16 $32 \mathrm{~h}$, 


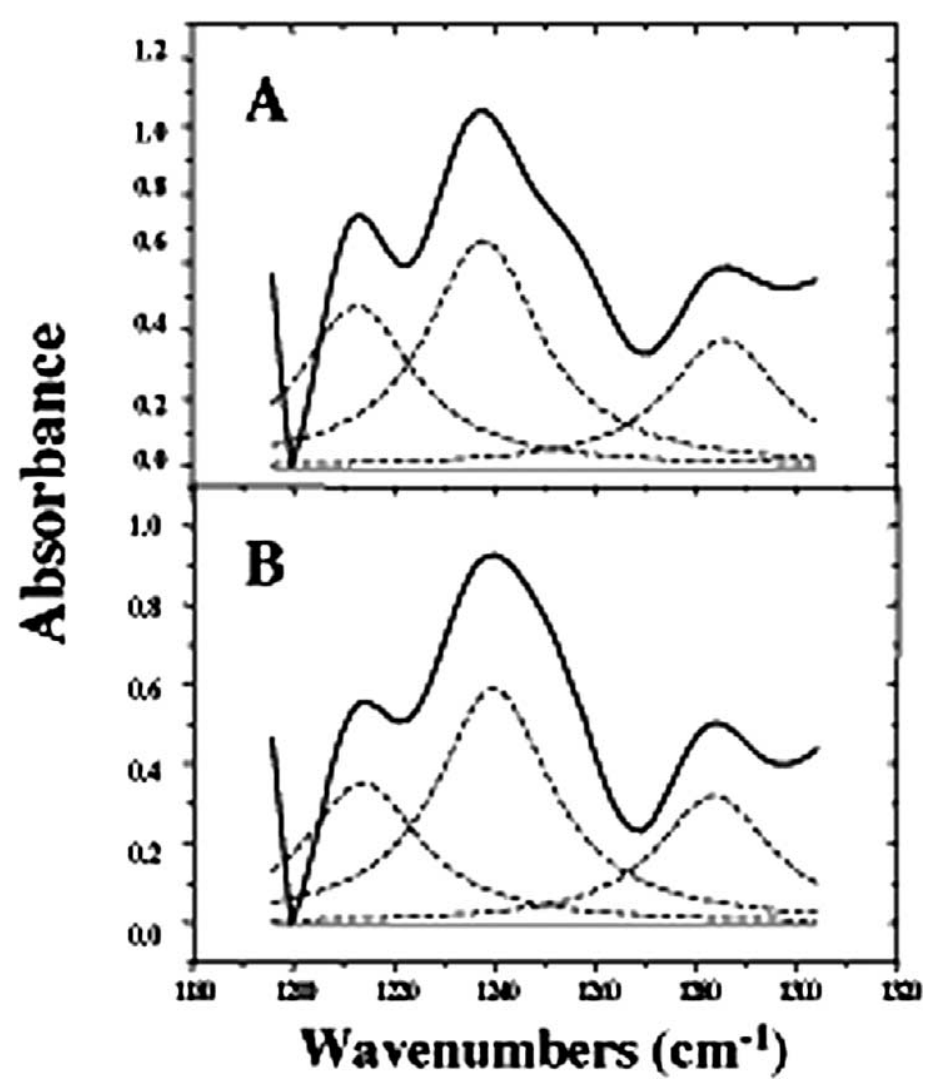

Fig. 6. Deconvoluted IR spectra in the frequency region $1180-1300 \mathrm{~cm}^{-1}$ of Jurkat cells with enhancement factor 3.0 and bandwidth $30 \mathrm{~cm}^{-1}$. (A) Normal cells; (B) cells after $32 \mathrm{~h}$ treatment with $50 \mu \mathrm{M}$ VP-16. Deconvoluted spectra (continuos line), spectral curve-fitting (dashed line).

$1.20 \pm 0.06$; VP-16 $32 \mathrm{~h}, 1.19 \pm 0.06$, respectively) whereas, in necrotic cells the values at 24,48 and $96 \mathrm{~h}$ were $0.87 \pm 0.03 ; 0.78 \pm 0.03: 0.88 \pm 0.03$ and $0.97 \pm 0.04 ; 0.96 \pm 0.04 ; 0.98 \pm 0.04$, respectively.

\subsection{The DNA region}

Analysis of the deconvoluted spectra of this region showed the presence of several peaks (Fig. 7). The bands around 965, 1087 and $1240 \mathrm{~cm}^{-1}$ are considered DNA bands. The $965 \mathrm{~cm}^{-1}$ band corresponds to $\mathrm{C}-\mathrm{C} / \mathrm{C}-\mathrm{O}$ stretching of deoxyribose and phosphate of DNA [2]. The band around $1087 \mathrm{~cm}^{-1}$ derives from the symmetric $\mathrm{PO}_{2}{ }^{-}\left(\nu_{\mathrm{s}} \mathrm{PO}_{2}{ }^{-}\right)$whereas the band around $1240 \mathrm{~cm}^{-1}$ originates from the asymmetric $\mathrm{PO}_{2}^{-}\left(\nu_{\mathrm{as}} \mathrm{PO}_{2}^{-}\right)$of the phosphate group of DNA [38]. The peak area ratio $\mathrm{A}_{1087} / \mathrm{A}_{1540}$ is often used to detect change of the DNA/protein content in the cell [35]. Compared to normal cells, we observed an increase of the ratio in Jurkat cells treated with VP-16 (control $0.37 \pm 0.03$ vs. $0.41 \pm 0.04,0.46 \pm 0.04$ and $0.47 \pm 0.04$ in the case of cell treated with VP-16 at 8,16 and $32 \mathrm{~h}$, respectively), indicating an increase in the DNA content of apoptotic cells $[2,36]$. These changes were not observed in necrotic cells in fact the $\mathrm{A}_{1087} / \mathrm{A}_{1540}$ value was $0.47 \pm 0.03 ; 0.48 \pm 0.04$ and $0.45 \pm 0.04$ at 24,48 and $96 \mathrm{~h}$, respectively. 


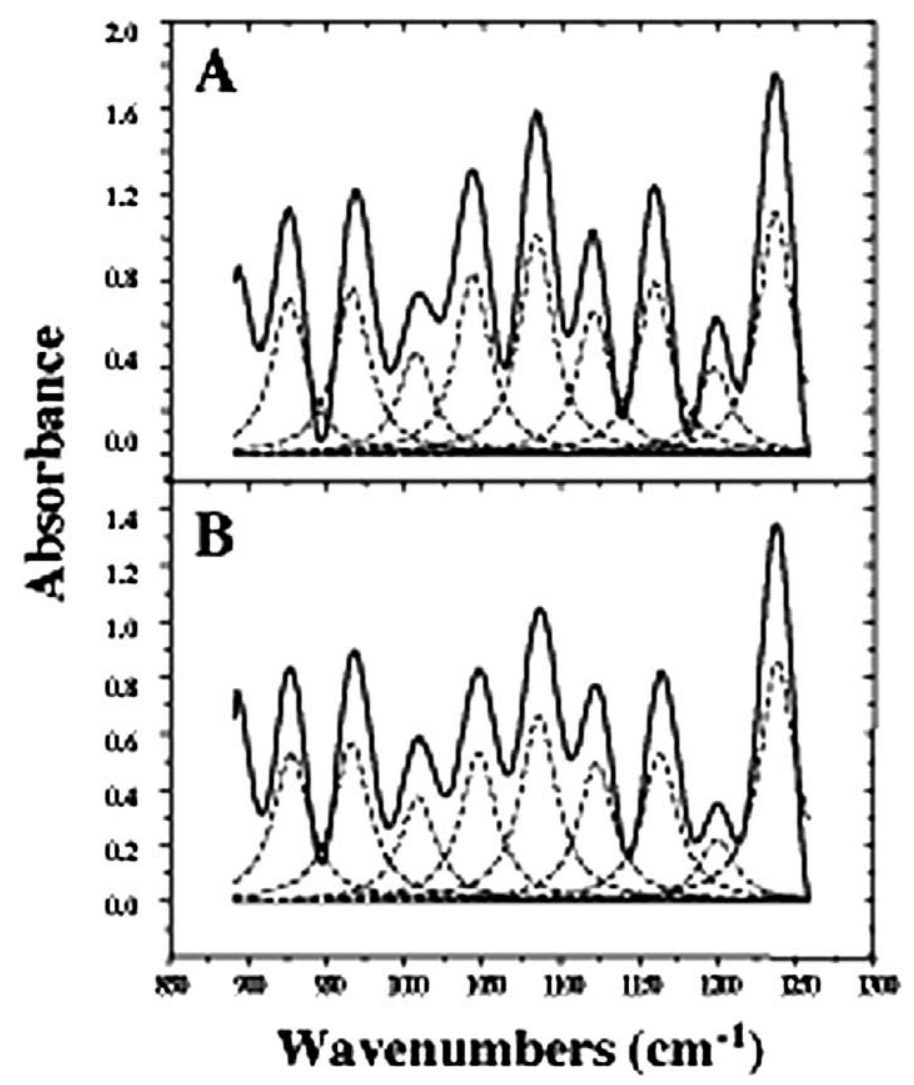

Fig. 7. Deconvoluted IR spectra in the frequency region $1300-800 \mathrm{~cm}^{-1}$ of Jurkat cells with enhancement factor 3.0 and bandwidth $30 \mathrm{~cm}^{-1}$. (A) Normal cells; (B) cells after $32 \mathrm{~h}$ treatment with $50 \mu \mathrm{M}$ VP-16. Deconvoluted spectra (continuous line), spectral curve-fitting (dashed line).

\section{Conclusion}

Cell death could be classified into two categories: (a) apoptosis, representing "active" programmed cell death, (b) necrosis, representing "passive" cell death. Both are distinguished by well defined morphological and biochemical features. Necrosis is characterized by cell swelling, disruption and rapid disintegration of the cell membrane [8] whereas in apoptosis, the cells undergo nuclear and cytoplasmic shrinkage, chromatin condensation and fragmentation, and finally the cells are broken into multiple membrane surrounded bodies (apoptotic bodies) [8]. In this work, we have compared FT-IR features of Jurkat cells during induced apoptosis and necrosis and some information were derived from the analysis of the spectra:

(A) In contrast to necrotic cells, the apoptotic cells were characterized by an increase in the $\mathrm{CH}_{2}$ absorption [32].

(B) The protein distribution in apoptotic cells indicates the presence of more $\alpha$-helical structures, whereas proteins in necrotic cells become rapidly more and more aggregated [39]. In fact, the $\mathrm{A}_{1654} / \mathrm{A}_{1629}$ observed in $\mathrm{H} 1355$ necrotic cells was even indicative of an increase of $\beta$-sheet content (nec $48 \mathrm{~h})$. 
(C) In apoptotic cells there was the appearance of a peak around $1743 \mathrm{~cm}^{-1}$. Because no other similar increase for lipid bands was observed, the increase of $A_{1745}$ is not simply due to an increase in the number of lipid molecules or their density but could also be indicative as marker of apoptosis.

\section{Acknowledgement}

This work was partially supported with a grant from MIUR, FIRB 2003 (RBLA033WJX_003).

\section{References}

[1] E. Benedetti, L. Teodori, M.L. Trinca, P. Vergamini, F. Papineschi, E. Benedetti, F. Mauro and G. Spremolla, Microchem. J. 46 (1992), 204-208.

[2] E. Benedetti, L. Teodori, M.L. Trinca, P. Vergamini, F. Salvati, F. Mauro and G. Spremolla, Appl. Spectrosc. 44 (1990), $1276-1280$.

[3] D.A. Cantrell, J. Cell Sci. 114 (2001), 1439-1445.

[4] M.A. Cohenford and B. Rigas, Proc. Natl. Acad. Sci. USA 95 (1998), 15327-15332.

[5] R. Eckel, H. Huoa, H.W. Guanb, X. Hub, X. Chea and W.D. Huang, Vibr. Spectrosc. 27 (2001), 165-173.

[6] H. Fabian, D. Chapman and H.H. Mantsch, in: Infrared Spectroscopy of Biomolecules, H.H. Mantsch and D. Chapman, eds, Wiley-Liss, New York, 1996, pp. 341-352.

[7] I. Fabian, D. Reuveni, A. Levitov, D. Halperin, E. Priel and I. Shalit, British J. Canc. 95 (2006), 1038-1046.

[8] W. Fiers, R. Beyaert, W. Declercq and P. Vandenabeele, Oncogene 18 (1999), 7719-7730.

[9] U.P. Fringeli and H.H. Gunthard, Infrared membrane spectroscopy, in: Membrane Spectroscopy, E. Grell, ed., Springer, Berlin, 1981, pp. 270-332.

[10] F. Gasparri and M. Muzio, Biochem. J. 369 (2003), 239-248.

[11] D.M. Haaland, H.D.T. Jones and E.V. Thomas, Appl. Spectrosc. 51 (1997), 340-345.

[12] P.I. Haris and D. Chapmann, Methods Mol. Biol. 22 (1994), 183-202.

[13] H.-Y.N. Holman, M.C. Martin and W.R. McKinney, Tracking chemical changes in a live cell: Biomedical applications of SR-FTIR spectromicroscopy, Spectroscopy 17 (2003), 139-160. Special issue: First International Conference on Biomedical Spectroscopy: From Molecules to Men.

[14] N. Jamin, P. Dumas, J. Moncuit, W.H. Fridman, J.L. Teillaud, G.L. Carr and G.P. Williams, Proc. Natl. Acad. Sci. USA 95 (1998), 4837-4840.

[15] A. Lamberti, O. Longo, M. Marra, P. Tagliaferri, E. Bismuto, A. Fiengo, C. Viscomi, A. Budillon, U.R. Rapp, E. Wang, S. Venuta, A. Abbruzzese, P. Arcari and M. Caraglia, Cell Death Differ. 14 (2007), 952-962.

[16] F. Lang, M. Ritter, N. Gamper, S. Huber, S. Tanneur, A. Lepple-Wienhues, I. Szabo and E. Bulbins, Cell Physiol. Biochem. 10 (2000), 417-428.

[17] K.A. Lee, R.A. Roth and J.J. LaPress, Pharmacol. Ther. 113 (2007), 229-246.

[18] D. Lin-Vien, N.B. Colthup, W.G. Fateley and J.G. Grasselli, The Handbook of Infrared and Raman Characteristic Frequencies of Organic Molecules, Academic Press, Boston, 1991, pp. 155-175.

[19] H.H. Mantsch and R.N. McElhaney, Chem. Phys. Lipids 57 (1991), 213-226.

[20] C.L. McDowell and E.T. Papoutsakis, Biotechnol. Bioeng. 14 (1998), 567-572.

[21] C.L. McDowell and E.T. Papoutsakis, Biotechnol. Bioeng. 60 (1998), 259-268.

[22] R. Mittler, in: When Cells Die: A Comprehensive Evaluation of Apoptosis and Programmed Cell Death, Z. Zakeri, J. Tilly and R.A. Lockshin, eds, Wiley, 1998, pp. 147-174.

[23] K.M. Omberg, J.C. Osborn, S.L. Zhang, J.P. Freyer, J.R. Mourant and J.R. Schoonover, Appl. Spectrosc. 56 (2002), 813819.

[24] F.S. Parker, Applications of Infrared Spectroscopy in Biochemistry, Biology, and Medicine, Plenum Press, New York, 1971.

[25] C. Petibois and G. Deleris, Analyst 129 (2004), 912-916.

[26] C. Petibois and G. Deleris, Cell Biol. Int. 29 (2005), 709-716.

[27] C. Petibois and G. Deleris, Trends Biotechnol. 24 (2006), 455-462.

[28] J. Ramesh, A. Salman, Z. Hammody, B. Cohen, J. Gopas, N. Grossman and S. Mordechai, Eur. Biophys. J. 30 (2001), $250-255$.

[29] B. Rigas, S. Morgello, I.S. Goldman and P.T.T. Wong, Proc. Natl. Acad. Sci. USA 87 (1990), 8140-8145.

[30] F. Schmidt, H.K. Hustoft, M. Strozynski, C. Dimmler, T. Rudel and B. Thiede, Electrophoresis 28 (2007), 4359-4368. 
[31] C.P. Schultz, K.Z. Liu, J.B. Johnston and H.H. Mantsch, Leuk. Res. 20 (1996), 649-655.

[32] C.P. Schultz, T. Bezabeh, M. Mowat, L. Jarolim, A.H. Greenberg, I.C.P. Smith and H.H. Mantsch, Distinction of early necrosis from apoptosis in human cervical carcinoma cells, in: ISMRM 6th Scientific Meeting and Exhibition - International Society for Magnetic Resonance in Medicine, Sydney, Australia, 1998, p. 616.

[33] S. Spiegel, J. Leukoc. Biol. 65 (1999), 341-344.

[34] W.K. Surewika and H.H. Mantsch, Biochim. Biophys. Acta 952 (1988), 115-130.

[35] R.E. Taillandie and F. Liquier, Methods Enzymol. 211 (1992), 307-335.

[36] Z. Wang, J. Zhou, S. Sun, M. Liu and H. Zhang, Tsinghua Sci. Technol. 6 (2001), 243-247.

[37] D.L. Wetzel and S.M. LeVine, Science 285 (1999), 1224-1225.

[38] P.T.T. Wong, R.K. Wong, T.A. Caputo, T.A. Godwin and B. Rigas, Proc. Natl. Acad. Sci. USA 88 (1991), 10988-10992.

[39] T. Yamada, N. Miyoshi, T. Ogawa, K. Akao, M. Fukuda, T. Ogasawara, Y. Kitagawa and K. Sano, Clin. Cancer Res. 8 (2002), 2010-2014.

[40] Z. Zakeri, in: When Cells Die: A Comprehensive Evaluation of Apoptosis and Programmed Cell Death, R.A. Lockshin, Z. Zakeri and J.L. Tilly, eds, Wiley-Liss, New York, 1998, pp. 97-129.

[41] J. Zhou, Z. Wang, S. Sun, M. Liu and H. Zhang, Biotechnol. Appl. Biochem. 33 (2001), 127-132. 


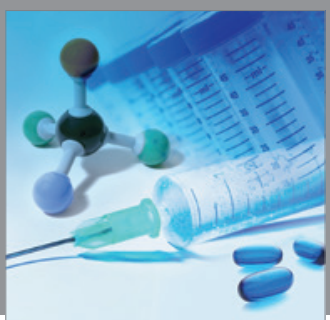

International Journal of

Medicinal Chemistry

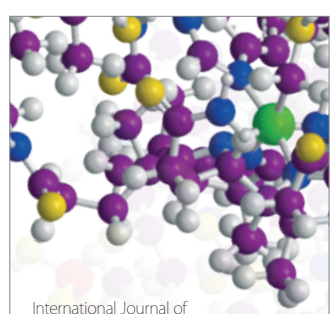

Carbohydrate Chemistry

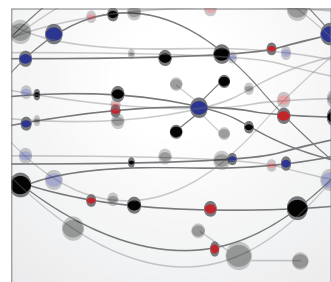

The Scientific World Journal
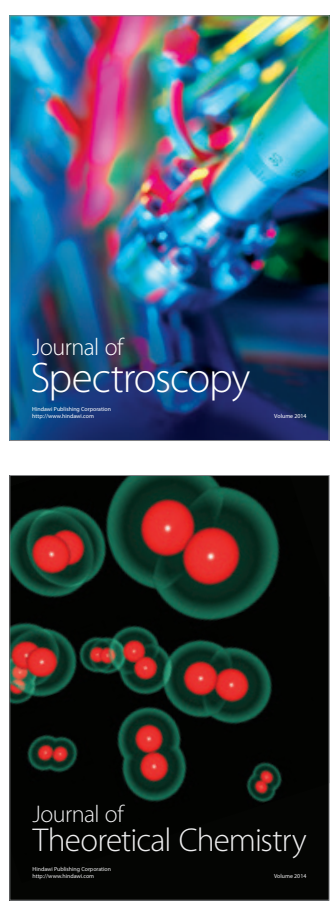
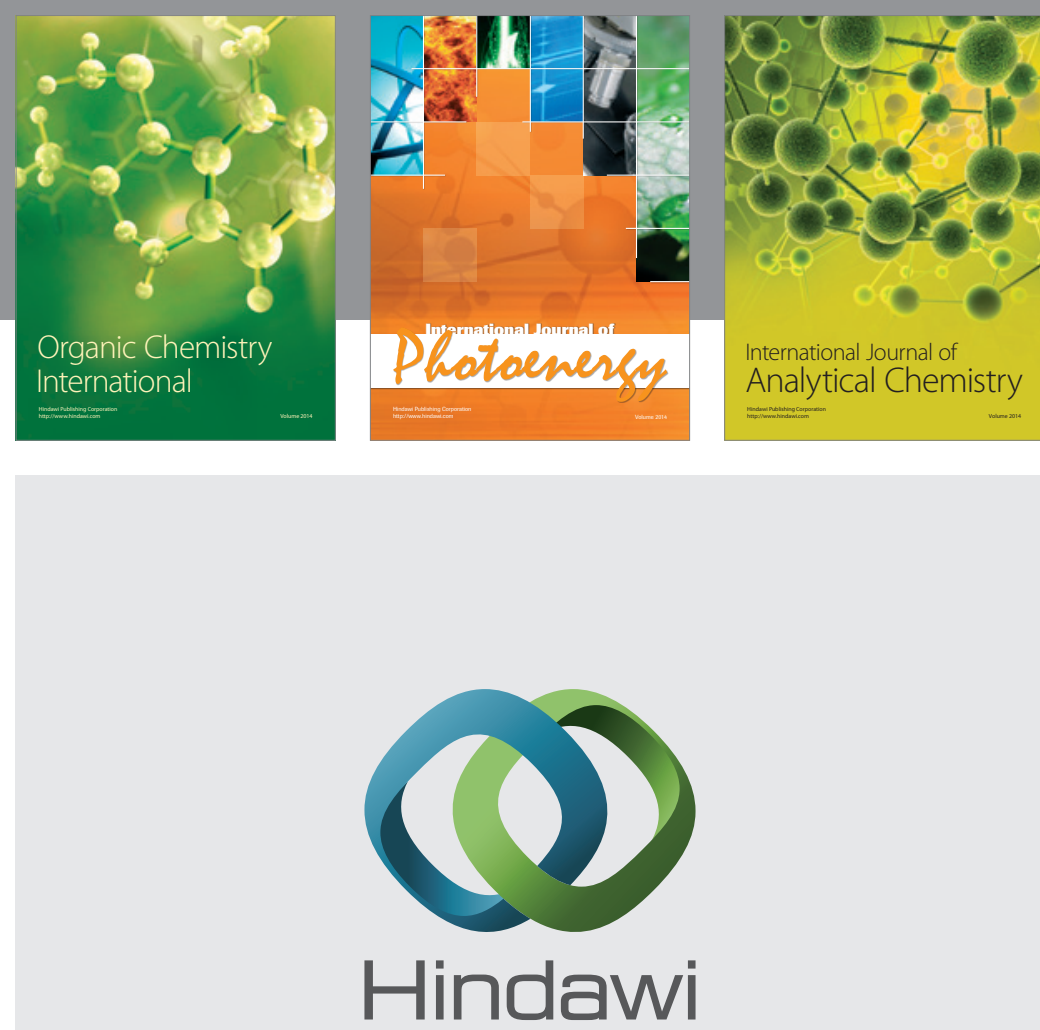

Submit your manuscripts at

http://www.hindawi.com
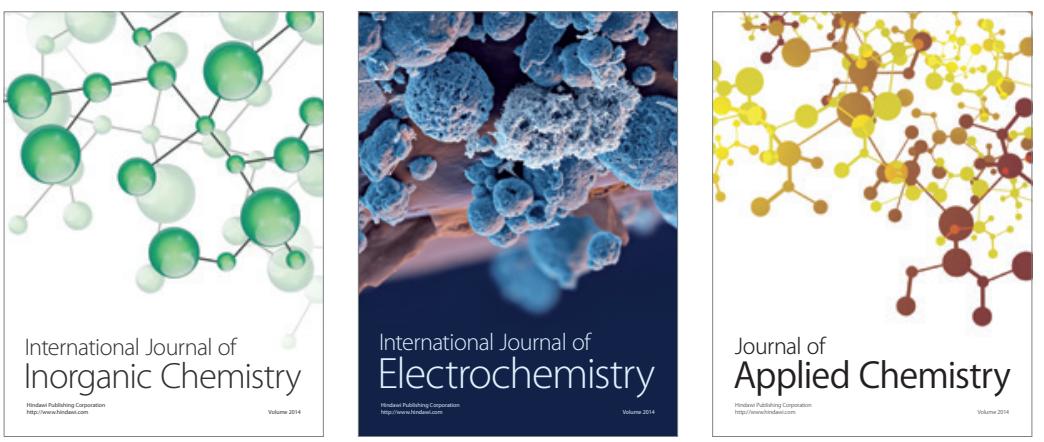

Journal of

Applied Chemistry
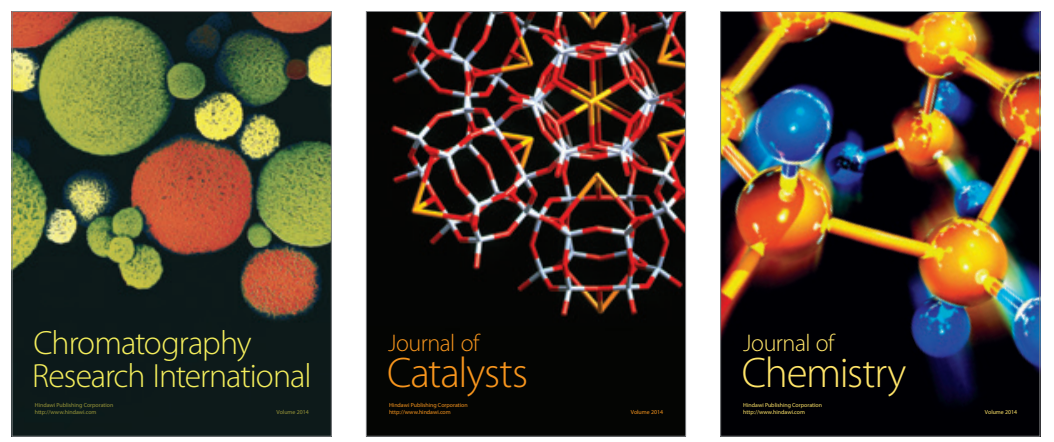
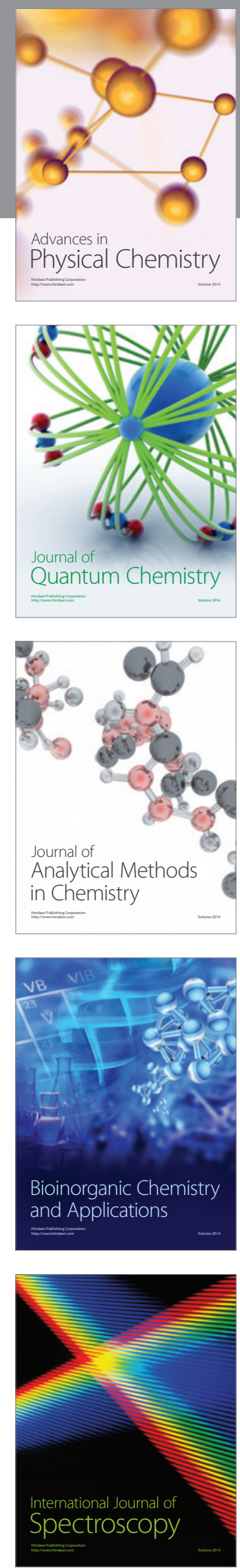